\title{
Effect of Amyloid $\beta$-Peptide On Permeability Transition Pore: A Comparative Study
}

\author{
Paula I. Moreira, ${ }^{1}$ Maria S. Santos, ${ }^{1}$ António Moreno,,${ }^{1}$ A. Cristina Rego, ${ }^{2}$ and \\ Catarina Oliveira ${ }^{2 \star}$ \\ ${ }^{1}$ Department of Zoology, University of Coimbra, Coimbra, Portugal \\ ${ }^{2}$ Department of Biochemistry, Faculty of Medicine, University of Coimbra, Coimbra, Portugal
}

A potentially central factor in neurodegeneration is the permeability transition pore (PTP). Because of the tissuespecific differences in pore properties, we directly compared isolated brain and liver mitochondria responses to the neurotoxic $A \beta$ peptides. For this purpose, the following parameters were examined: mitochondrial membrane potential $(\Delta \Psi \mathrm{m})$, respiration, swelling, ultrastructural morphology, and content of cytochrome c. Both peptides, $A \beta_{25-35}(50 \mu \mathrm{M})$ and $A \beta_{1-40}(2 \mu \mathrm{M})$, had a similar toxicity, exacerbating the effects of $\mathrm{Ca}^{2+}$, although, per se, they did not induce (PTP). In liver mitochondria, $A \beta$ led to a drop in $\Delta \Psi \mathrm{m}$ and potentiated matrix swelling and disruption induced by $\mathrm{Ca}^{2+}$. In contrast, brain mitochondria, exposed to the same conditions, demonstrated a higher capacity to accumulate $\mathrm{Ca}^{2+}$ before the $\Delta \Psi \mathrm{m}$ drop and a slight increase of mitochondrial swelling compared with liver mitochondria. Furthermore, mitochondrial respiratory state 3 was depressed in the presence of $A \beta$, whereas state 4 was unaltered, resulting in an uncoupling of respiration. In both types of mitochondria, $A \beta$ did not affect the content of cytochrome $c$. The $\Delta \Psi \mathrm{m}$ drop was reversed when $\mathrm{Ca}^{2+}$ was removed by EGTA or when ADP plus oligomycin was present. Pretreatment with cyclosporin A or ADP plus oligomycin prevented the deleterious effects promoted by $A \beta$ and/or $\mathrm{Ca}^{2+}$. It can be concluded that brain and liver mitochondria show a different susceptibility to the deleterious effect of $A \beta$ peptide, brain mitochondria being more resistant to the potentiation by $\mathrm{A} \beta$ of $\mathrm{Ca}^{2+}$-induced PTP. () 2002 Wiley-Liss, Inc.

Key words: $\beta$-amyloid peptide; permeability transition pore; mitochondria membrane potential; neurodegeneration

The main constituents of senile plaques, one of the hallmarks of Alzheimer's disease (AD), are deposits of 39-43 amino acids long, abnormal protein aggregates called $\beta$-amyloid (A $\beta$ ) (Glenner and Wong, 1984; Selkoe et al., 1996). A smaller, 11-residue fragment of $A \beta\left(A \beta_{25}\right.$ 35) possesses much of the biological activity of the fulllength peptide, including the capacity to generate free radicals. Oxidative stress transforms soluble $A \beta$ into insoluble and, consequently, toxic $A \beta$ aggregates in vitro (Dyrks et al., 1992). A $\beta$ itself has been shown to be a source of free radicals, probably because of distortions of the electronic structure of $A \beta$, resulting in "radicalization" of the peptide (Hensley et al., 1994). It has been suggested that internalized $A \beta$, through intimate contacts with intracellular recognition sites, directly damages membranes of intracellular organelles, namely, the mitochondria internal membrane associated with the mitochondria respiratory chain (MRC) (Pike and Cotman, 1993). The consequent dysfunction of MRC enhances the production of reactive oxygen species (ROS) and compromises neurons' viability as a result of energy depletion. Pereira et al. (1999) showed, in PC12 cells, that A $\beta$ induces mitochondrial dysfunction and impairment of glycolysis, leading to ATP depletion, by a mechanism involving the generation of ROS.

Mitochondrial oxidative damage is a major factor in many human disorders, including neurodegenerative diseases and aging (Shigenaga et al., 1994; Beal, 1995, 1996). The continuous electron leak from the respiratory chain leads to the generation of damaging ROS, whose first target is mitochondria (Richter and Kass, 1991; Beal, 1996; Cay and Jones, 1999). Mitochondrial oxidative damage leads to the impairment of ATP synthesis and calcium homeostasis and induces the permeability transition pore (PTP) (Shigenaga et al., 1994; Broekemeier and Pfeiffer, 1995; Berman et al., 2000), leading to necrotic or apoptotic cell death (Gunter et al., 1994; Zoratti and Szabo, 1995). The PTP is a nonselective, highconductance channel that spans the inner and outer mi-

Contract grant sponsor: FCT (Portuguese Research Council).

*Correspondence to: Catarina Resende de Oliveira, Center for Neuroscience and Cellular Biology of Coimbra, Department of BiochemistryFaculty of Medicine, University of Coimbra, 3004-504 Coimbra, Portugal. E-mail: catarina@cnc.cj.uc.pt

Received 14 January 2002; Revised 18 March 2002; Accepted 18 March 2002 
tochondrial membrane (Bernardi et al., 1994; Zoratti and Szabo, 1995; Bernardi and Petronilli, 1996). Experimentally, induction of the PTP is characterized by an abrupt swelling and depolarization of mitochondrial membrane, accompanied by the efflux of mitochondrial calcium, reduced glutathione (GSH), and NAD (P)H (Bernardi, 1992; Petronilli et al., 1994), which are inhibited by the immunosuppressant cyclosporin A (CsA) (Broekemeier et al., 1989). Most of the studies relative to PTP have been obtained by using mitochondria isolated from tissues such as heart, liver, and skeletal muscle. Recent studies give support to the hypothesis that, at least under certain circumstances, a PTP is also assembled in brain mitochondria (Andreyev et al., 1998; Berman et al., 2000).

In several studies (Cassarino et al., 1998, 1999), data obtained with liver mitochondria have been extrapolated to brain. However, it is well known that metabolic differences between tissues do in fact exist, leading to controversial conclusions. Accordingly, the goal of our study was to investigate and compare the effects of $A \beta$ on permeability transition induced by $\mathrm{Ca}^{2+}$ on brain and liver mitochondria. Mitochondrial transmembrane potential $(\Delta \Psi \mathrm{m})$, respiration, swelling, ultrastructural morphology, and cytochrome c content were the parameters studied.

\section{MATERIALS AND METHODS}

\section{Chemicals}

$A \beta$ peptide fragments $\left(A \beta_{25-35}\right.$ and $\left.A \beta_{1-40}\right)$ were obtained from Bachem AG (Bubendorf, Germany). Protease (Subtilisin, Carlsberg) type VIII was obtained from Sigma (Portugal). Digitonin was obtained from Calbiochem (Portugal). Cytochrome $\mathrm{c}$ antibodies, against denatured forms, were obtained from PharMingen (San Diego, CA). All the other chemicals were of the highest grade of purity commercially available.

\section{Animals}

Male Wistar rats (6 weeks old) were kept under controlled conditions with respect to light, temperature, and humidity and with free access to water and food. Experimental animals were sacrificed by cervical displacement and decapitation. All animal procedures were approved by the Institutional Animal Care and Use Committee.

\section{Isolation of Mitochondria}

Brain mitochondria. Brain mitochondria were isolated from male Wistar rats (6 weeks old) by a method previously described (Rosenthal et al., 1987), with slight modifications. The rats were killed by decapitation, and the brains were rapidly removed and homogenized at $4^{\circ} \mathrm{C}$ in $10 \mathrm{ml}$ of isolation medium (225 mM mannitol, $75 \mathrm{mM}$ sucrose, $5 \mathrm{mM}$ HEPES, $1 \mathrm{mM}$ EGTA, $1 \mathrm{mg} / \mathrm{ml}$ bovine serum albumin, $\mathrm{pH}$ 7.4) containing $5 \mathrm{mg}$ of the bacterial protease type VIII (Subtilisin). Brain homogenates were brought to $30 \mathrm{ml}$ and then centrifuged at $2,000 \mathrm{~g}$ for $3 \mathrm{~min}$. The pellet was resuspended in $10 \mathrm{ml}$ of the isolation medium containing $0.02 \%$ digitonin (which sets free mitochondria from the synaptosomal fraction) and centrifuged at $12,000 \mathrm{~g}$ for $8 \mathrm{~min}$. The mitochondrial pellet was resuspended in $10 \mathrm{ml}$ of medium and recentrifuged at $12,000 \mathrm{~g}$ for $10 \mathrm{~min}$.
Finally, the mitochondrial pellet was resuspended in $200 \mu$ l of resuspension medium $(225 \mathrm{mM}$ mannitol, $75 \mathrm{mM}$ sucrose, $5 \mathrm{mM}$ HEPES, $\mathrm{pH}$ 7.4). Mitochondrial protein was determined by the biuret method, calibrated with bovine serum albumin (Gornall et al., 1949).

Liver mitochondria. Wistar rats (6 weeks old) were killed by cervical displacement, and mitochondria were isolated by conventional methods (Gazzoti et al., 1979), with slight modifications. Briefly, liver mitochondria were isolated in a medium containing $210 \mathrm{mM}$ mannitol, $70 \mathrm{mM}$ sucrose, $5 \mathrm{mM}$ HEPES, $0.2 \mathrm{mM}$ EGTA, $0.1 \mathrm{mM}$ EDTA, and $0.1 \%$ bovine serum albumin ( $\mathrm{pH}$ 7.2). EDTA, EGTA, and bovine serum albumin were omitted from the final washing medium. The mitochondrial pellet was washed twice and suspended in the washing medium. Mitochondrial protein was determined by the biuret method, calibrated with bovine serum albumin (Gornall et al., 1949). The functionality of isolated mitochondria was evaluated by the determination of respiratory control ratio (RCR).

\section{$\Delta \Psi \mathrm{m}$ Measurements}

The $\Delta \Psi \mathrm{m}$ was monitored by evaluating transmembrane distribution of the lipophilic cation tetraphenylphosphonium ion $\left(\mathrm{TPP}^{+}\right)$with a $\mathrm{TPP}^{+}$-selective electrode prepared according to Kamo et al. (1979) using a calomel electrode as reference. $\mathrm{TPP}^{+}$uptake has been measured from the decreased $\mathrm{TPP}^{+}$ concentration in the medium sensed by the electrode. The potential difference between the selective electrode and the reference electrode was measured with an electrometer and recorded continuously in a Linear 1200 recorder. The voltage response of the $\mathrm{TPP}^{+}$electrode to $\log \left[\mathrm{TPP}^{+}\right]$was linear, with a slope of $59 \pm 1$, in good agreement with the Nernst equation. Reactions were carried out in a chamber with magnetic stirring in $1 \mathrm{ml}$ of the standard medium $(100 \mathrm{mM}$ sucrose, $100 \mathrm{mM}$ $\mathrm{KCl}, 2 \mathrm{mM} \mathrm{KH} \mathrm{PO}_{4}, 10 \mu \mathrm{M}$ EGTA, 5 mM HEPES, $\mathrm{pH}$ 7.4, supplemented with $2 \mu \mathrm{M}$ rotenone) containing $3 \mu \mathrm{M} \mathrm{TPP}^{+}$. This $\mathrm{TPP}^{+}$concentration was chosen to achieve high sensitivity in measurements and to avoid possible toxic effects on mitochondria (Jensen and Gunter, 1984; Wingrove and Gunter, 1985). The $\Delta \Psi \mathrm{m}$ was estimated by the equation:

$$
\Delta \Psi \mathrm{m}(\mathrm{mV})=59 \log (\mathrm{v} / \mathrm{V})-59 \log \left(10^{\Delta \mathrm{E} / 59}-1\right),
$$

as indicated by Kamo et al. (1979) and Muratsugu et al. (1977). v, V, and $\Delta \mathrm{E}$ stand for mitochondrial volume, volume of the incubation medium, and deflection of the electrode potential from the baseline, respectively. This equation was derived assuming that $\mathrm{TPP}^{+}$distribution between the mitochondria and the medium follows the Nernst equation and that the law of mass conservation is applicable. A matrix volume of $1.1 \mu \mathrm{l} / \mathrm{mg}$ protein was assumed. No correction was made for the "passive" binding contribution of $\mathrm{TPP}^{+}$to the mitochondrial membranes, because the purpose of the experiments was to show relative changes in potentials rather than absolute values. As a consequence, we can anticipate a slight overestimation on $\Delta \Psi \mathrm{m}$ values. However, the overestimation is significant only at $\Delta \Psi \mathrm{m}$ values below $90 \mathrm{mV}$ and, 
therefore, far from our measurements. Nevertheless, the nonspecific binding of $\mathrm{TPP}^{+}$to the membrane was checked by using appropriate deenergizing inhibitors to demonstrate that $A \beta$ peptides do not affect this binding.

The assays were started by adding $5 \mathrm{mM}$ succinate to mitochondria in suspension at $0.8 \mathrm{mg}$ protein $/ \mathrm{ml}$. After a steady-state distribution of $\mathrm{TPP}^{+}$had been reached $(\sim 2$ min of recording), $\mathrm{Ca}^{2+}$ was added and $\Delta \Psi \mathrm{m}$ fluctuations were recorded. $A \beta_{25-35}$ and $A \beta_{1-40}$ were incubated 5 min before succinate addition, whereas $0.85 \mu \mathrm{M}$ CsA and $2 \mu \mathrm{g} / \mathrm{ml}$ oligomycin plus $1 \mathrm{mM}$ ADP were added $2 \mathrm{~min}$ prior to $A \beta$ preincubation or mitochondria energization.

\section{Mitochondrial Respiration}

Oxygen consumption of isolated mitochondria was monitored polarographically with a Clarck oxygen electrode (Estabrook, 1967) connected to a suitable recorder in a $1 \mathrm{ml}$ thermostatted, water-jacketed closed chamber with magnetic stirring. The reactions were carried out at $30^{\circ} \mathrm{C}$ in $1 \mathrm{ml}$ of the standard medium with $0.8 \mathrm{mg}$ protein. $\mathrm{A} \beta_{25-35}(50$ or $100 \mu \mathrm{M})$ was incubated $5 \mathrm{~min}$ before $5 \mathrm{mM}$ succinate addition, whereas $0.85 \mu \mathrm{M}$ CsA and $2 \mu \mathrm{g} / \mathrm{ml}$ oligomycin plus $1 \mathrm{mM}$ ADP were added 2 min prior to $A \beta$ preincubation or mitochondria energization.

State 3 respiration is defined as consumption of oxygen in the presence of substrate and ADP. State 4 respiration is defined as consumption of oxygen after the ADP has been consumed; $\mathrm{RCR}=$ state $3 /$ state 4 .

\section{Mitochondrial Swelling}

Mitochondrial osmotic volume changes were estimated by changes in light scattering (apparent absorbance changes) as monitored spectrophotometrically at $540 \mathrm{~nm}$ (Henry et al., 1995; Palmeira and Wallace, 1997). The reactions, stirred continuously, were carried out at $30^{\circ} \mathrm{C}$ in $2 \mathrm{ml}$ of the standard medium. Mitochondria were suspended at $0.5 \mathrm{mg}$ protein $/ \mathrm{ml}$ of standard medium. The reaction was stirred continuously and the temperature maintained at $30^{\circ} \mathrm{C}$. Mitochondria were energized with $5 \mathrm{mM}$ succinate for 2 min before adding $\mathrm{Ca}^{2+}$ at varying concentrations. Where indicated, $A \beta_{25-35}(50$ or $100 \mu \mathrm{M})$ was incubated for $5 \mathrm{~min}$ before succinate addition, whereas $0.85 \mu \mathrm{M}$ CsA and $2 \mu \mathrm{g} / \mathrm{ml}$ oligomycin plus $1 \mathrm{mM}$ ADP were added 2 min prior to $A \beta_{25-35}$ preincubation or mitochondria energization. None of these reagents interfered with the spectrophotometric analysis.

\section{Electron Microscopy}

Mitochondria were fixed for electron microscopy by the addition of $3 \%$ glutaraldehyde in $0.1 \mathrm{M}$ sodium cacodylate

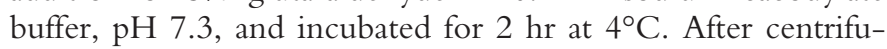
gation $(15,000 \mathrm{~g}, 3 \mathrm{~min})$, pellets were washed with $0.1 \mathrm{M}$ sodium cacodylate buffer, $\mathrm{pH}$ 7.3. The fixed and washed pellet was ressuspended in $1 \%$ osmium tetroxide $\left(\mathrm{OsO}_{4}\right)$ buffered with sodium cacodylate $0.1 \mathrm{M}, \mathrm{pH}$ 7.3. After $2 \mathrm{hr}$ of incubation, membranes were washed with cacodylate buffer ( $\mathrm{pH}$ 7.3; without $\mathrm{OsO}_{4}$ ). After preincubation in $1 \%$ agar, the samples were dehydrated in grade ethanol and embedded in Spurr. The ultrathin sections were obtained in an LKB ultramycrotome Ultrotome III and stained with methanolic uranyl acetate, followed by lead citrate, and examined with a Jeol Jem-100SV electron microscope operated at $80 \mathrm{kV}$.

\section{Cytochrome c Content}

At the end of the $\Delta \Psi \mathrm{m}$ experiments, each mitochondrial suspension was rapidly centrifuged at 14,000 rpm for $6 \mathrm{~min}$. The resulting pellets were resolved on $15 \%$ gels for SDS-PAGE, after denaturation at $100^{\circ} \mathrm{C}$, for $5 \mathrm{~min}$, in buffer containing $100 \mathrm{mM}$ Tris-HCl, pH 6.8, $200 \mathrm{mM}$ dithriothreitol (DTT), 4\% SDS, $0.2 \%$ bromophenol blue, and $20 \%$ glycerol. The proteins were electrotransferred onto PVDF membranes (Hybond-P), and, after transfer, the membranes were incubated overnight at $0-4^{\circ} \mathrm{C}$ in blocking buffer $(25 \mathrm{mM}$ Tris- $\mathrm{HCl}, \mathrm{pH} 7.6,150 \mathrm{mM}$ $\mathrm{NaCl}$, and $0.05 \%$ Tween-20) containing $5 \%$ fat-free milk. Then, the blots were incubated with the antibody anticytochrome $c$ (PharMingen) against the denatured form of the protein (1:1,000 dilution in blocking buffer containing $1 \%$ fatfree milk) for $2 \mathrm{hr}$ at room temperature (RT) with gentle shaking. After washes in blocking buffer (three times, $5 \mathrm{~min}$ each), the immunoblots were incubated for $1 \mathrm{hr}$ at $\mathrm{RT}$ with anti-mouse antibody alkaline phosphatase (1:1,000 dilution in blocking buffer containing 1\% fat-free milk) (Amersham Pharmacia Biotech, Arlington Heights, IL), followed by an ECF substrate detection using a Storm (860 Molecular Analysis) scanner for band visualization. Cytochrome c content was quantified by determining the areas of each band; these quantifications were automatically performed by a computer program.

\section{Statistical Analysis}

Results are presented as mean (percentage of control) \pm SEM of the indicated number of experiments. Statistical significance was determined using Student's $t$-test, with $P<0.05$ considered significant.

\section{RESULTS}

\section{Effect of $A \beta_{25-35}$ and $A \beta_{1-40}$ on $\Delta \Psi \mathrm{m}$}

The $\Delta \Psi \mathrm{m}$ drop is a typical phenomenon that follows the induction of PTP. Figure 1 shows the alteration of $\Delta \Psi \mathrm{m}$ induced by $\mathrm{A} \beta_{25-35}$ preincubated for $5 \mathrm{~min}$ at $30^{\circ} \mathrm{C}$ with mitochondria. Under brain control conditions (Fig. $1 \mathrm{Aa}$ ), the addition of $5 \mathrm{mM}$ succinate produced a $\Delta \Psi \mathrm{m}$ of $\sim 190 \mathrm{mV}$ (negative inside mitochondria), corresponding to respiratory state 4 . Then, the first and second pulses of $\mathrm{Ca}^{2+}$ led to rapid depolarizations (decrease of $\Delta \Psi \mathrm{m}$ ), followed by repolarizations (recovery of $\Delta \Psi \mathrm{m}$ ). The depolarizations were due to the entry of $\mathrm{Ca}^{2+}$ into the electronegative mitochondrial matrix, followed by efflux of $\mathrm{H}^{+}$and restoration of $\Delta \Psi \mathrm{m}$. However, a third pulse of $\mathrm{Ca}^{2+}$ led to a total depolarization of mitochondria after a smaller repolarization. Mitochondria can tolerate some amount of $\mathrm{Ca}^{2+}$, but ultimately their capacity to adapt to $\mathrm{Ca}^{2+}$ loads is overwhelmed, and mitochondria depolarize completely because of a profound change in the inner membrane permeability, i.e., the opening of PTP. The collapse of the $\Delta \Psi \mathrm{m}$ is prevented by adding EGTA (a $\mathrm{Ca}^{2+}$-chelating agent) or oligomycin (an inhibitor of ADP phosphorylation) plus ADP (an inhibitor of PTP), which further led to a complete restoration of $\Delta \Psi \mathrm{m}$ to the level 


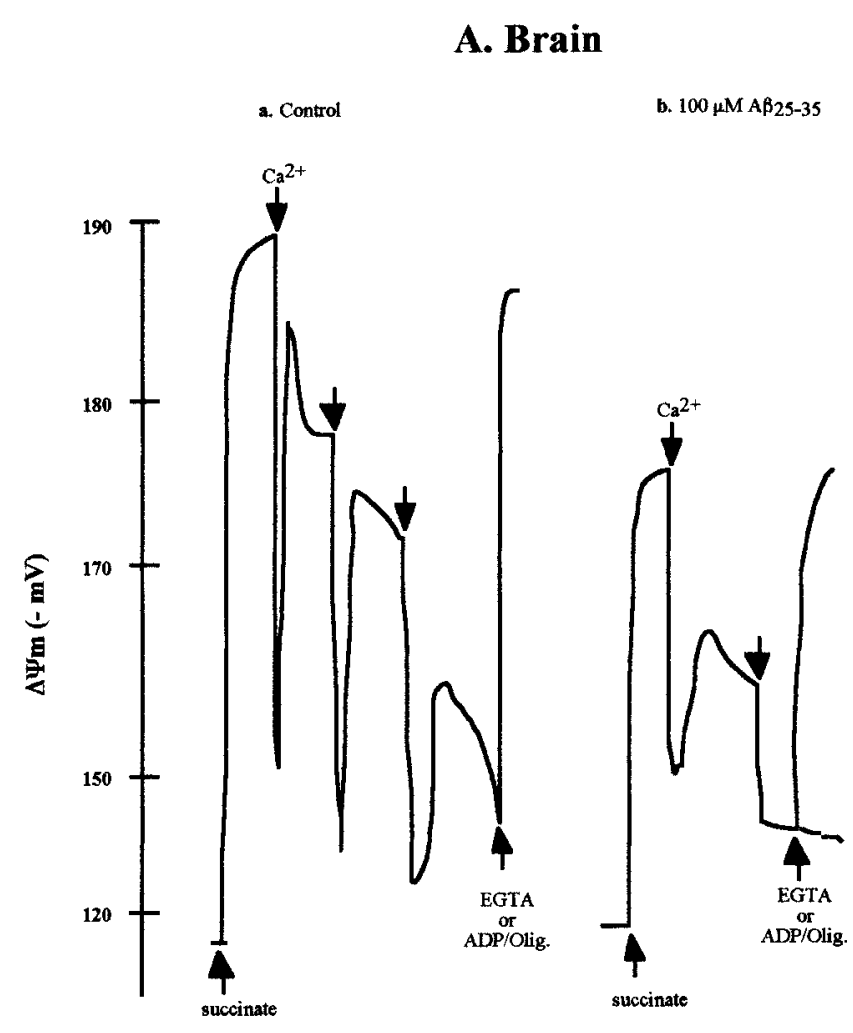

B. Liver

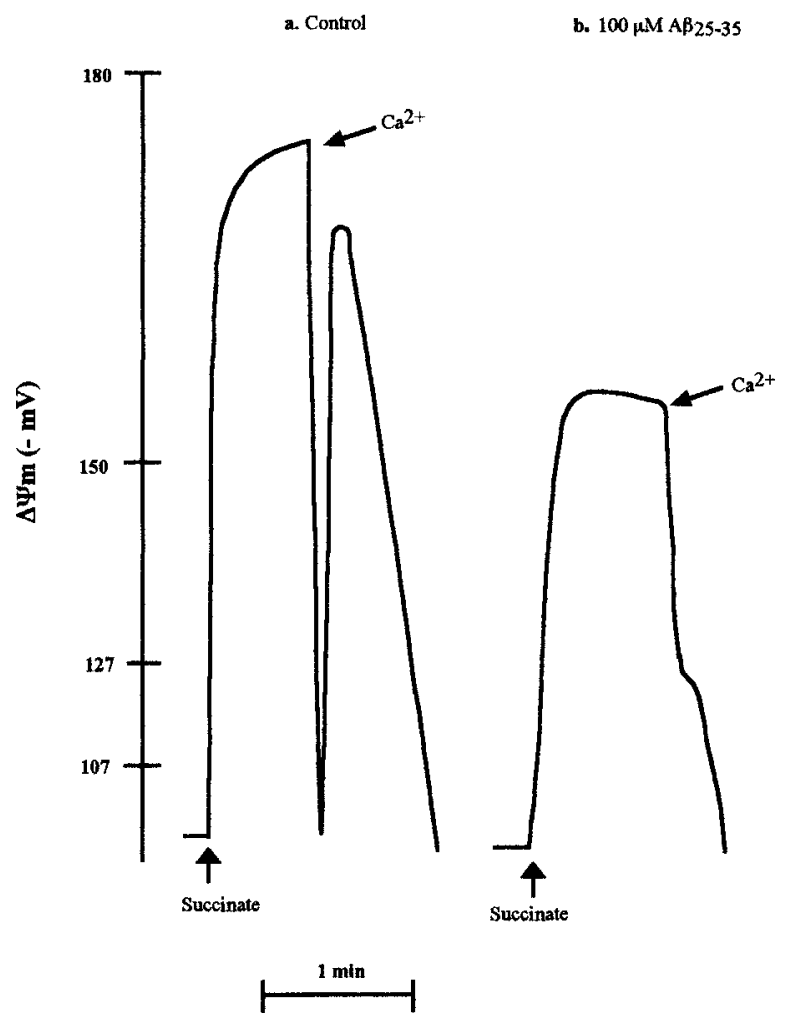

of respiratory state 4 (i.e., before $\mathrm{Ca}^{2+}$ addition). $\Delta \Psi \mathrm{m}$ measured under control conditions, with or without $5 \mathrm{~min}$ of preincubation at $30^{\circ} \mathrm{C}$, did not present significant alterations (data not shown). In the presence of $A \beta_{25-35}$ $(100 \mu \mathrm{M})$ (Fig. 1Ab), a significant decrease of $\Delta \Psi \mathrm{\Psi}$, measured after mitochondria energization, occurred. In the presence of $A \beta_{25-35}$, the mitochondria were more susceptible to the amount of $\mathrm{Ca}^{2+}$ added, undergoing PTP in the presence of lower $\mathrm{Ca}^{2+}$ concentrations (after two $\mathrm{Ca}^{2+}$ challenges) compared to the control mitochondria. Figure $1 \mathrm{~B}$ shows the alteration of $\Delta \Psi \mathrm{m}$ induced by $A \beta_{25-35}$ in liver mitochondria. Under control conditions (Fig. 1Ba), after the energization of liver mitochondria with succinate, the first pulse of $\mathrm{Ca}^{2+}$ led to a rapid depolarization, followed by repolarization. However, this repolarization was not sustained, and the $\Delta \Psi \mathrm{m}$ dropped to basal values. The collapse of $\Delta \Psi \mathrm{m}$ was prevented by adding EGTA or oligomycin plus ADP, which further led to a complete restoration of the $\Delta \Psi \mathrm{m}$ to levels observed at respiratory state 4 (i.e., before $\mathrm{Ca}^{2+}$ addition) (data not shown). In the presence of $A \beta_{25-35}(100 \mu \mathrm{M})$ (Fig. 1Bb), a significant decrease of $\Delta \Psi \mathrm{m}$, measured after mitochondria energization, occurred. Figure $2 \mathrm{~A}$ shows that $2 \mu \mathrm{M}$ $\mathrm{A} \beta_{1-40}$ had a similar effect on brain $\Delta \Psi \mathrm{m}$ compared with that induced by $50 \mu \mathrm{M} \mathrm{A} \beta_{25-35}$ (Fig. 2B), indicative of the higher toxicity inherent to $A \beta_{1-40}$ compared with $\mathrm{A} \beta_{25-35}$. The preincubation (2 min) of mitochondria with $1 \mathrm{mM}$ ADP plus $2 \mu \mathrm{g} / \mathrm{ml}$ oligomycin completely prevented mitochondrial membrane depolarization, by increasing dramatically the repolarization capacity of mitochondrial membrane after $\mathrm{Ca}^{2+}$ accumulation (Fig. 3Aa). Additionally, the presence of $0.85 \mu \mathrm{M}$ cyclosporin A (CsA) (a specific inhibitor of PTP) added 2 min prior to $\mathrm{A} \beta_{25-35}$ and/or $\mathrm{Ca}^{2+}$ afforded a clear protection of mitochondria, because it prevents the depolarization induced by $\mathrm{Ca}^{2+}$ when $A \beta_{25-35}$ is present (Fig. $3 \mathrm{Ab}, \mathrm{Ba}$ ).

\section{Effect of $\mathbf{A} \boldsymbol{\beta}_{25-35}$ on Mitochondrial Respiration}

Induction of the mitochondrial permeability transition by $A \beta_{25-35}$ is further evidenced by the effect on mitochondrial respiration (Fig. 4A,B). Addition of $100 \mu \mathrm{M} \mathrm{Ca}^{2+}$ (Fig. 4Aa) to brain mitochondria caused a transient increase in the rate of oxygen consumption, followed by a rapid returning to state 4 . However, when the mitochondria were preincubated for $5 \mathrm{~min}$ with $50 \mu \mathrm{M}$ (Fig. 4Ab) and $100 \mu \mathrm{M} \mathrm{A} \beta_{25-35}$ (Fig. 4Ac), addition of $100 \mu \mathrm{M} \mathrm{Ca}^{2+}$ resulted in a complete uncoupling of respiration; i.e., in the presence of $\mathrm{Ca}^{2+}$, mitochondria shown no difference in state 3 and state 4 of

Fig. 1. Effect of $A \beta_{25-35}$ on the mitochondrial membrane potential $(\Delta \Psi \mathrm{m})$. Freshly isolated brain (A) and liver $(\mathbf{B})$ mitochondria $(0.8 \mathrm{mg})$ in $1 \mathrm{ml}$ of the standard medium supplemented with $3 \mu \mathrm{M} \mathrm{TPP}{ }^{+}$ and $2 \mu \mathrm{M}$ rotenone were energized with $5 \mathrm{mM}$ succinate. a: $\mathrm{Ca}^{2+}$ $(100 \mu \mathrm{M})$ was added $2 \mathrm{~min}$ after mitochondria energization; b: $100 \mu \mathrm{M}$ $\mathrm{A} \beta_{25-35}$ was preincubated for $5 \mathrm{~min}$ at $30^{\circ} \mathrm{C}$ before mitochondria energization. The traces represent typical direct recordings from five independent experiments with different mitochondrial preparations. 


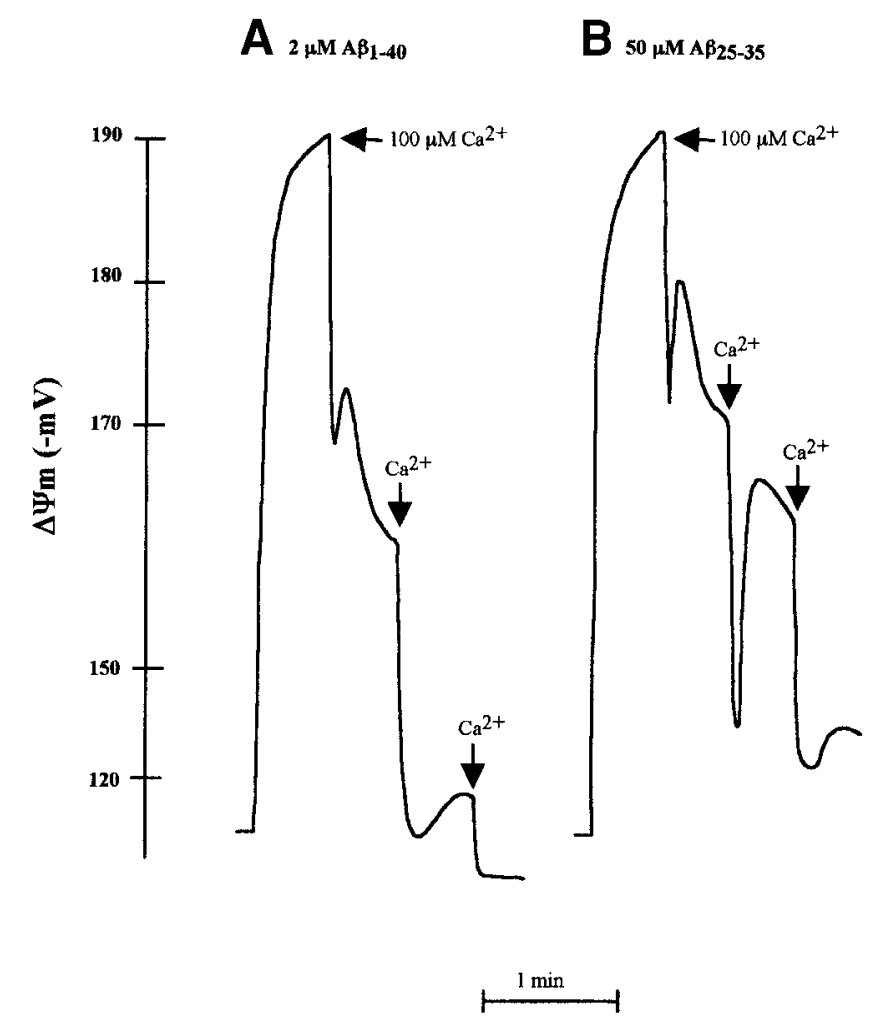

Fig. 2. Effect of $A \beta_{1-40}$ on the mitochondrial membrane potential $(\Delta \Psi \mathrm{m})$. Freshly isolated brain mitochondria $(0.8 \mathrm{mg})$ in $1 \mathrm{ml}$ of the standard medium supplemented with $3 \mu \mathrm{M} \mathrm{TPP}{ }^{+}$and $2 \mu \mathrm{M}$ rotenone were energized with $5 \mathrm{mM}$ succinate. B: $50 \mu \mathrm{M} \mathrm{A} \beta_{25-35}$ was preincubated $5 \mathrm{~min}$ at $30^{\circ} \mathrm{C}$ before mitochondria energization. A: $2 \mu \mathrm{M}$ $\mathrm{A} \beta_{1-40}$ was preincubated $5 \mathrm{~min}$ at $30^{\circ} \mathrm{C}$ before mitochondria energization. The traces represent typical direct recordings from three independent experiments with different mitochondrial preparations.

respiration. In liver mitochondria, the addition of $100 \mu \mathrm{M}$ $\mathrm{Ca}^{2+}$ is sufficient to cause the uncoupling of respiration (Fig. 4Ba), independently of the presence or absence of $\mathrm{A} \beta_{25-35}$ (Fig. 4Bb).

Preincubation ( $2 \mathrm{~min}$ ) of both types of mitochondria with $1 \mathrm{mM}$ ADP plus $2 \mu \mathrm{g} / \mathrm{ml}$ oligomycin or $0.85 \mu \mathrm{M}$ CsA afforded clear protection, because they prevent the uncoupling of mitochondrial respiration induced by $\mathrm{Ca}^{2+}$ and $A \beta_{25-35}$ (Fig. 4Ad,e,Bc,d). The effects of CsA or $\mathrm{ADP} /$ oligomycin in eliminating $\mathrm{Ca}^{2+}$ and $\mathrm{A} \beta_{25-35}$ depolarization were remarkable in that mitochondria could withstand successive additions of $\mathrm{Ca}^{2+}$, without becoming uncoupled. Respiratory rates characteristic of state 4 (succinate alone) and state 3 (ADP-stimulated respiration) are summarized in the Figure 4A,B insets. In both types of mitochondria, state 3 respiration was shown to be decreased in the presence of $A \beta_{25-35}$ compared with control conditions, whereas state 4 remained unaltered.

\section{Effect of $\mathbf{A} \boldsymbol{\beta}_{25-35}$ on Mitochondrial Swelling}

Usually, induction of the PTP is monitored by following the decrease in absorbance associated with mito-
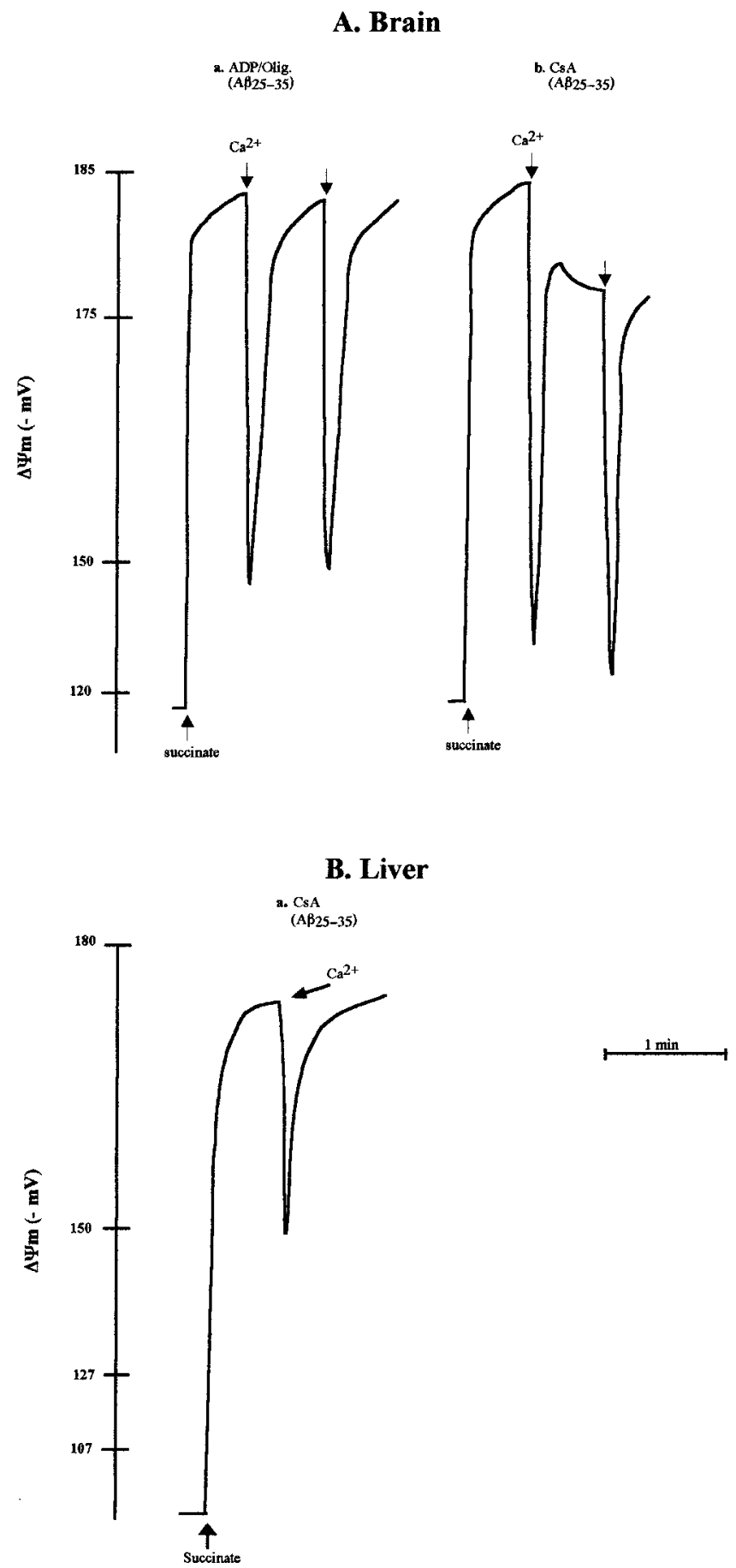

Fig. 3. Inhibitory effect of CsA and oligomycin plus ADP on $A \beta_{25-35}$-dependent permeability transition pore opening. Brain (A) and liver $(\mathbf{B})$ mitochondria were incubated at $0.8 \mathrm{mg}$ protein $/ \mathrm{ml}$ under standard conditions, as described in Materials and Methods. CsA at 0.85 $\mu \mathrm{M}(\mathrm{Ab}, \mathrm{Ba})$ and $1 \mathrm{mM}$ ADP plus $2 \mu \mathrm{g} / \mathrm{ml}$ oligomycin ( $\mathrm{Aa}$ ) were incubated with mitochondria for 2 min before adding $A \beta_{25-35} . A \beta_{25-35}$ was added $5 \mathrm{~min}$ before energizing the mitochondria with $5 \mathrm{mM}$ succinate. The traces are typical of four or five experiments. 

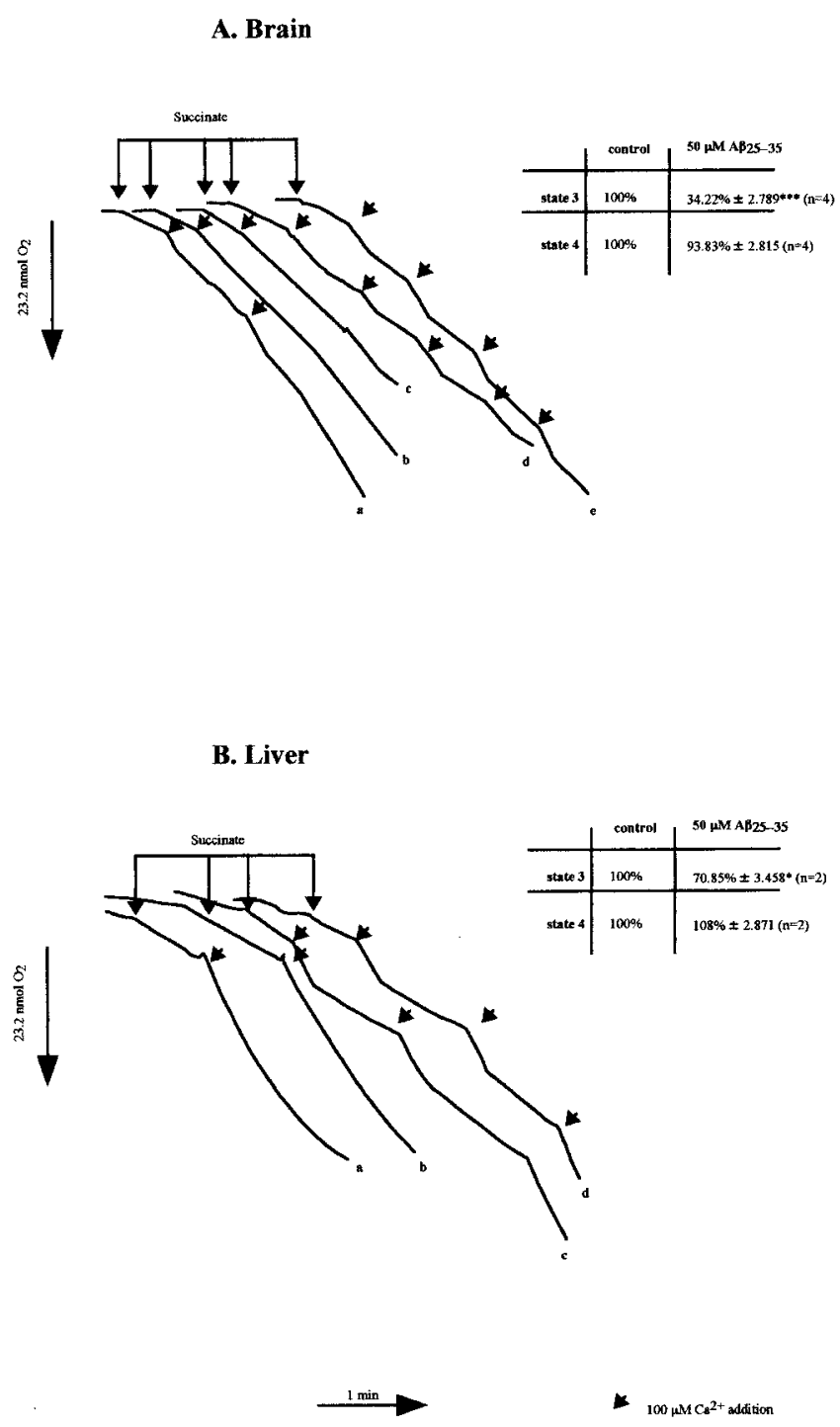

Fig. 4. Effect of $A \beta_{25-35}$ on mitochondria respiration. Freshly isolated brain $(\mathbf{A})$ and liver $(\mathbf{B})$ mitochondria $(0.8 \mathrm{mg})$ in $1 \mathrm{ml}$ of the standard medium supplemented with $2 \mu \mathrm{M}$ rotenone were energized with $5 \mathrm{mM}$ succinate. Aa,Ba: $\mathrm{Ca}^{2+}(100 \mu \mathrm{M})$ was added 2 min after mitochondria energization. $A \beta_{25-35}$ at $50 \mu \mathrm{M}(\mathrm{Ab})$ and $100 \mu \mathrm{M}$ $\mathrm{A} \beta_{25-35}(\mathrm{Ac}, \mathrm{Bb})$ were preincubated for $5 \mathrm{~min}$ at $30^{\circ} \mathrm{C}$ before mitochondria energization. ADP at $1 \mathrm{mM}$ plus $2 \mu \mathrm{g} / \mathrm{ml}$ oligomycin (Ad,Bc) and $0.85 \mu \mathrm{M}$ CsA (Ae,Bd), respectively, were incubated with mitochondria for $2 \mathrm{~min}$ before adding $A \beta_{25-35}$. The traces represent typical direct recordings from of five independent experiments with different mitochondrial preparations. $\star \star \star P<0.001 ; \star{ }^{\star} P<0.05$ when compared with control condition.

chondrial swelling. The addition of increasing concentrations of $\mathrm{Ca}^{2+}$ resulted in a decrement of the absorbance (mitochondrial swelling), which is indicative that mitochondria have a finite capacity to accumulate $\mathrm{Ca}^{2+}$ before undergoing PTP (Fig. 5Bd,g). A $\beta_{25-35}$ potentiated the effect of $\mathrm{Ca}^{2+}$ on swelling also in a concentrationdependent manner (Fig. 5Be,f,h), and CsA (0.85 $\mu \mathrm{M})$
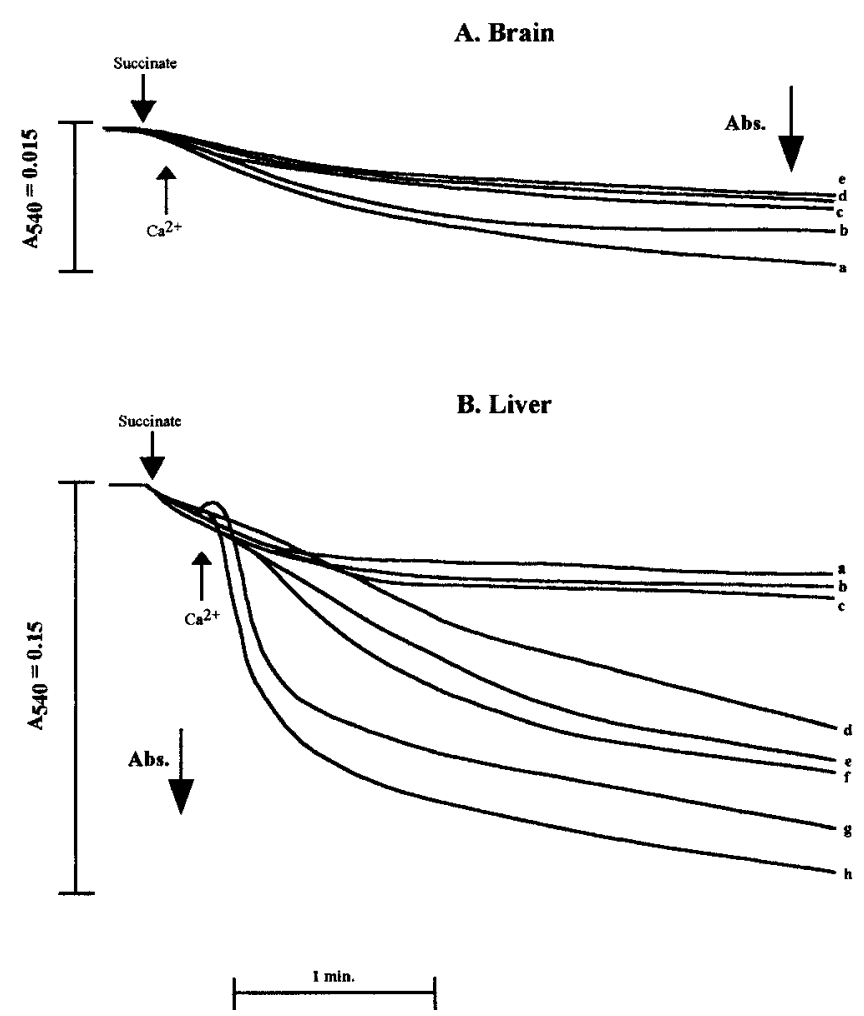

Fig. 5. Effect of $A \beta_{25-35}$ on mitochondrial swelling. Mitochondria were incubated at $0.5 \mathrm{mg}$ protein $/ \mathrm{ml}$ under standard conditions as described in Materials and Methods; 2 min before $\mathrm{Ca}^{2+}$ addition and 5 min after $A \beta_{25-35}$ preincubation, standard medium was supplemented with $5 \mathrm{mM}$ succinate; $0.85 \mu \mathrm{M}$ CsA was added to the reaction medium 2 min prior $\mathrm{Ca}^{2+}$ or $\mathrm{A} \beta_{25-35}$ preincubation. A: Brain mitochondria. a: Control; b: $100 \mu \mathrm{M} \mathrm{Ca}^{2+}$; c: $300 \mu \mathrm{M} \mathrm{Ca}^{2+}$; d: $50 \mu \mathrm{M} \mathrm{A} \beta_{25-35}$ plus $100 \mu \mathrm{M} \mathrm{Ca}^{2+}$; e: $100 \mu \mathrm{M} \mathrm{A} \beta_{25-35}$ plus $100 \mu \mathrm{M} \mathrm{Ca}^{2+}$. B: Liver mitochondria. a: Control; b: $100 \mu \mathrm{M} \mathrm{A} \beta_{25-35}$; c: $0.85 \mu \mathrm{M}$ CsA plus $50 \mu \mathrm{M} \mathrm{A}_{25-35}$ plus $50 \mu \mathrm{M} \mathrm{Ca}^{2+}$; d: $50 \mu \mathrm{M} \mathrm{Ca}^{2+}$; e: $50 \mu \mathrm{M} \mathrm{A}_{25-35}$ plus $50 \mu \mathrm{M} \mathrm{Ca}^{2+}$; f: $50 \mu \mathrm{M} \mathrm{A} \beta_{25-35}$ plus $100 \mu \mathrm{M} \mathrm{Ca}^{2+}$; g: $200 \mu \mathrm{M}$ $\mathrm{Ca}^{2+}$; h: $100 / 50 \mu \mathrm{MA} \beta_{25-35}$ plus $200 \mu \mathrm{M} \mathrm{Ca}^{2+}$. The traces are typical of three experiments.

protected against the decrease in absorbance induced by $\mathrm{A} \beta_{25-35}$ and/or $\mathrm{Ca}^{2+}$ (Fig. 5Bc). $A \beta_{25-35}$ per se did not induce a significant decrement of absorbance (Fig. 5Bb).

In contrast to what was observed in liver mitochondria, addition of $\mathrm{Ca}^{2+}$ to brain mitochondria induced an increase in absorbance (Fig. $5 \mathrm{Ab}, \mathrm{c}$ ). $\mathrm{A} \beta_{25-35}$ per se did not induce an absorbance decrement but potentiated the increase in absorbance mediated by $\mathrm{Ca}^{2+}$ (Fig. 5Ad,e).

\section{Effect of $\mathbf{A} \boldsymbol{\beta}_{25-35}$ on Mitochondrial Ultrastructural Morphology}

Figure 6Aa shows a heterogeneous population of brain mitochondria, some mitochondria being smaller than others. All mitochondria were also shown to contain dense cristae. Incubation with $100 \mu \mathrm{M} \mathrm{Ca}^{2+}$ induced only a small increase in mitochondria volume (Fig. 6Ab). In the presence of $100 \mu \mathrm{MA} \beta_{25-35}$ plus $100 \mu \mathrm{M} \mathrm{Ca}^{2+}$ (Fig. 


\section{A. Brain}

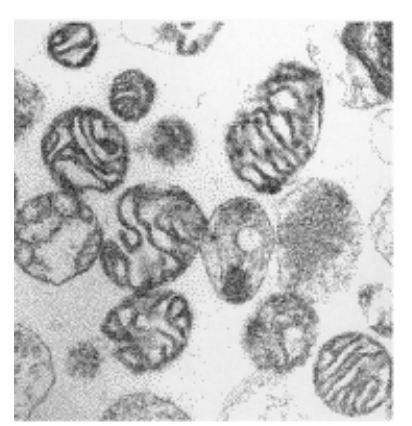

$\mathbf{a}$

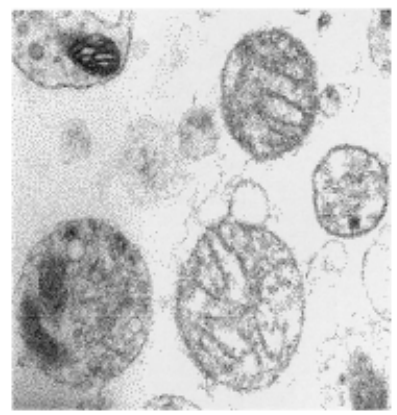

b

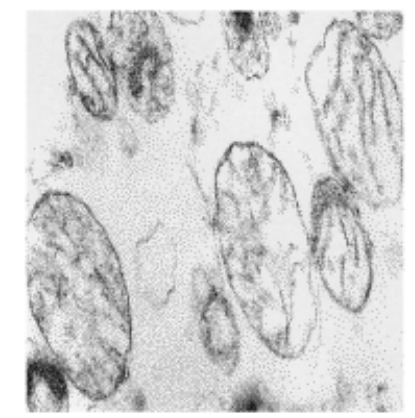

c

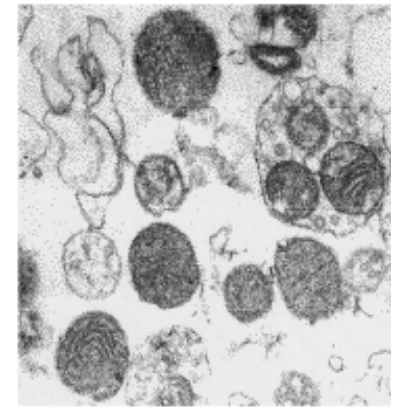

d

\section{B. Liver}

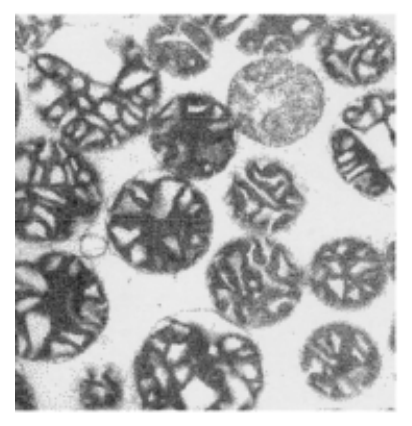

$\mathbf{a}$

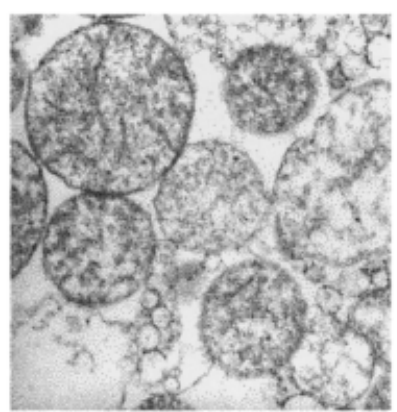

b

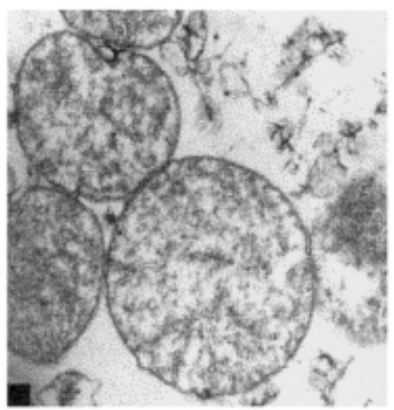

c

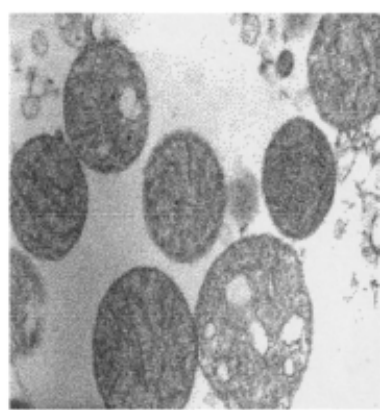

d

Fig. 6. Effect of $A \beta_{25-35}$ on mitochondrial ultrastructural morphology. At the end of incubations such as those described for Figure 1, suspensions of either rat brain (A) or rat liver $(\mathbf{B})$ mitochondria were centrifuged and processed for electron microscopy as described in Materials and Methods. Aa,Ba: Control; Ab,Bb: $100 \mu \mathrm{M} \mathrm{Ca}^{2+}$; Ac,Bc: $100 \mu \mathrm{M} \mathrm{A} \beta_{25-35}$ plus $100 \mu \mathrm{M} \mathrm{Ca}^{2+}$; Ad: $1 \mathrm{mM}$ ADP plus $2 \mu \mathrm{g} / \mathrm{ml}$ oligomycin plus $100 \mu \mathrm{M} \mathrm{A} \beta_{25-35}$ plus $100 \mu \mathrm{M} \mathrm{Ca}^{2+}$; Bd: $0.85 \mu \mathrm{M}$ CsA plus $100 \mu \mathrm{M}$ $\mathrm{A} \beta_{25-35}$ plus $100 \mu \mathrm{M} \mathrm{Ca}^{2+}$.

6Ac), an enlargement and deformation of brain mitochondria, with cristae disruption, were observed. ADP (1 mM) plus oligomycin $(2 \mu \mathrm{g} / \mathrm{ml}$ ) (Fig. 6Ad) protected mitochondria against the effects induced by these toxic agents, and mitochondria seemed to adopt a conformation with more compact cristae compared with control mitochondria. A similar protective effect was observed in the presence of $0.85 \mu \mathrm{M}$ CsA (data not shown).

Under control conditions (Fig. 6Ba), rat liver mitochondria appeared as a homogeneous population of larger mitochondria compared with control brain mitochondria.
Addition of $100 \mu \mathrm{M} \mathrm{Ca}^{2+}$ induced mitochondria enlargement, with disruption of some cristae (Fig. $6 \mathrm{Bb}$ ). $\mathrm{A} \beta_{25}-35$ $(100 \mu \mathrm{M})$ potentiated the effect exerted by $100 \mu \mathrm{M} \mathrm{Ca}{ }^{2}+$, leading to mitochondria swelling and less compacted cristae (Fig. 6Bc). CsA $(0.85 \mu \mathrm{M})$ (Fig. 6Bd) prevented the swelling and cristae destruction induced by $100 \mu \mathrm{M}$ $\mathrm{A} \beta_{25-35}$ plus $100 \mu \mathrm{M} \mathrm{Ca}^{2+}$, and, similarly to brain mitochondria, liver mitochondria seemed to acquire a more compact organization of the cristae. ADP $(1 \mathrm{mM})$ plus oligomycin $(2 \mu \mathrm{g} / \mathrm{ml})$ showed a similar protective effect (data not shown). 

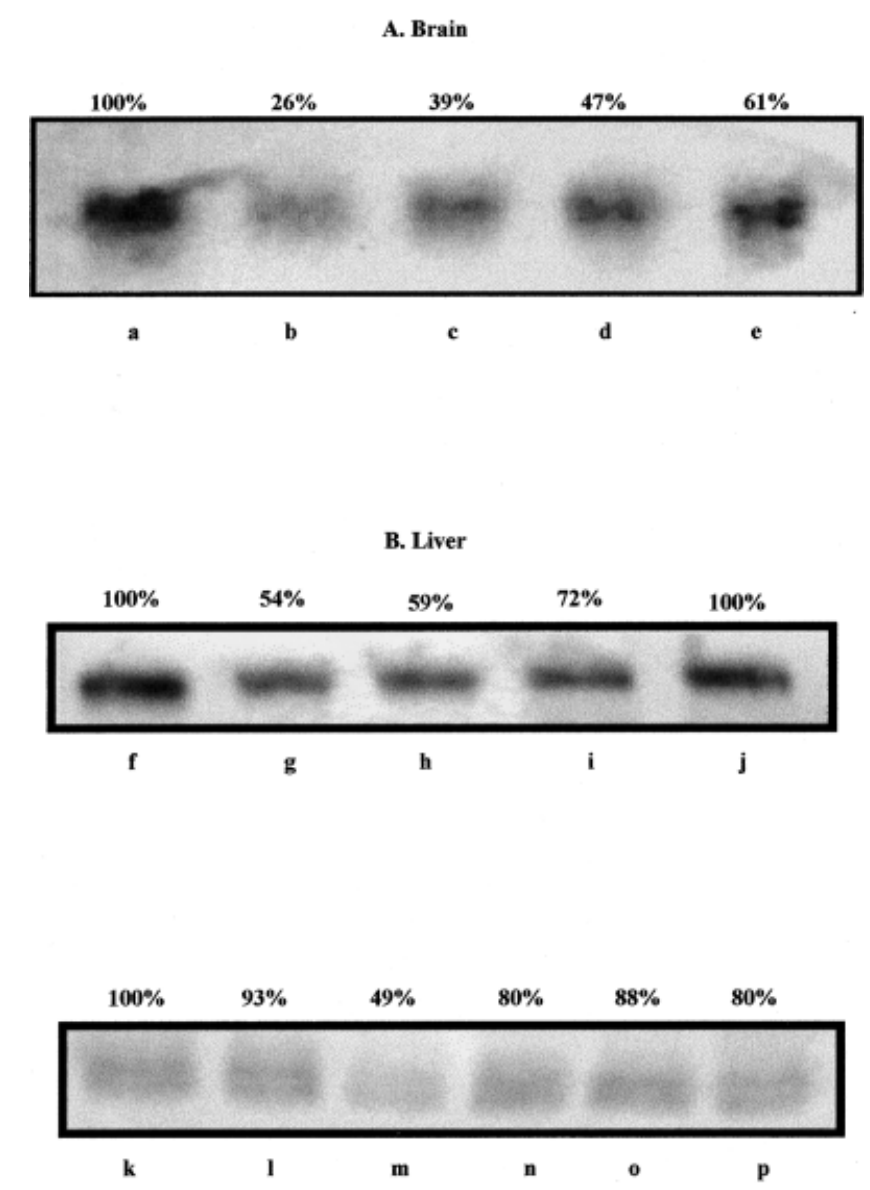

Fig. 7. Effect of $A \beta_{25-35}$ on cytochrome $c$ content. At the end of incubations such as those described for Figure 1, suspensions of either rat brain (A) or rat liver (B) mitochondria were centrifuged and the pellets used for immunoblot analysis of cytochrome $\mathrm{c}$ content (see Materials and Methods). Aa,Bf,Bk: Control; Ab,Bg,Bm: $100 \mu \mathrm{M}$ $\mathrm{Ca}^{2+}$; Ac,Bh: $50 \mu \mathrm{M} \mathrm{A} \beta_{25-35}$ plus $100 \mu \mathrm{M} \mathrm{Ca}^{2+}$; Ad,Bi: $1 \mathrm{mM}$ ADP plus $2 \mu \mathrm{g} / \mathrm{ml}$ oligomycin plus $50 \mu \mathrm{M} \mathrm{A} \beta_{25-35}$ plus $100 \mu \mathrm{M} \mathrm{Ca}^{2+}$; Ae: $1 \mathrm{mM}$ ADP plus $2 \mu \mathrm{g} / \mathrm{ml}$ oligomycin plus $50 \mu \mathrm{m} \mathrm{A} \beta_{25-35}$ plus $100 \mu \mathrm{M}$ $\mathrm{Ca}^{2+}$. Bj: $0.85 \mu \mathrm{M}$ CsA plus $50 \mu \mathrm{M} \mathrm{A} \beta_{25-35}$ plus $100 \mu \mathrm{M} \mathrm{Ca}^{2+}$; $\mathrm{Bl}$ : $1 \mathrm{mM}$ ADP plus $2 \mu \mathrm{g} / \mathrm{ml}$ plus $100 \mu \mathrm{M} \mathrm{Ca}^{2+}$; Bn: $50 \mu \mathrm{M} \mathrm{A} \beta_{25-35}$; Bo: $1 \mathrm{mM}$ ADP plus $2 \mu \mathrm{g} / \mathrm{ml}$ oligomycin; Bp: $0.85 \mu \mathrm{M}$ CsA.

\section{Effect of $A \boldsymbol{\beta}_{25-35}$ on Cytochrome c Content}

At the end of the experiments, such as those presented in Figures 1 and 2, each mitochondrial suspension was rapidly centrifuged, and the pellets were used for immunoblot determinations of cytochrome $\mathrm{c}$. Addition of $100 \mu \mathrm{M} \mathrm{Ca}^{2+}$ to brain (Fig. 7Ab) and liver (Fig. 7Bg) mitochondria led to a large decrement in cytochrome $\mathrm{c}$ content. However, $50 \mu \mathrm{M} \mathrm{A} \beta_{25-35}$ either alone (Fig. $7 \mathrm{Bn}$ ) or in the presence of $100 \mu \mathrm{M} \mathrm{Ca}^{2+}$ (Fig. 7Ac,Bh) did not affect cytochrome $c$ content. The release of cytochrome $\mathrm{c}$ was prevented in the presence of CsA $(0.85 \mu \mathrm{M})$ (Fig. $7 \mathrm{Bj})$ or ADP $(1 \mathrm{mM})$ plus oligomycin $(2 \mu \mathrm{g} / \mathrm{ml})$ (Fig.7Ae). Furthermore, those agents, per se, did not affect cytochrome c content. (Fig. 7Bo,p).

\section{DISCUSSION}

The existence of tissue-specific differences in mitochondria pore properties has been described (Berman et al., 2000). Accordingly, a comparative study of the responses of isolated brain and liver mitochondria to $A \beta$, was performed. The $\Delta \Psi \mathrm{m}$, mitochondrial respiration, swelling, ultrastructural morphology, and cytochrome c content were the parameters analyzed.

Our study clearly demonstrates that $A \beta$ potentiates the permeability transition in brain and liver mitochondria induced by $\mathrm{Ca}^{2+}$. However, its capacity to promote PTP is different in the two types of mitochondria, depending on the resistance of the brain and liver mitochondria populations to toxic insults. Brain mitochondria possess a higher capacity to resist to the deleterious effects promoted by $A \beta$ peptide than liver mitochondria.

A strict requirement for matrix $\mathrm{Ca}^{2+}$ and a selective inhibition by CsA (Bernardi, 1992; Zoratti and Szabo, 1995) have been recognized to be key features of PTP. Similarly to what has been described from other studies (Andreyev et al., 1998; Berman et al., 2000), brain mitochondria were shown to be more resistant to $\mathrm{Ca}^{2+}$ insults than liver mitochondria. Accordingly, we observed a large, CsA-inhibited decrease in absorbance (Fig. 5Bd,g) and a drastic alteration in the ultrastructural morphology of liver mitochondria (Fig. 6Bb). In contrast, brain mitochondria did not undergo large-amplitude swelling (Fig. $6 \mathrm{Ab}$ ), and an increase in spectrophotometric absorbance was further observed (Fig. 5Ab,c). Similar observations were previously associated with $\mathrm{Ca}^{2+}$ precipitation within brain mitochondria (Andreyev et al., 1998). The formation of $\mathrm{Ca}^{2+}$ crystals was suggested to obscure a decrease in spectrophotometric absorbance. However, other studies demonstrated the existence of brain mitochondrial swelling (Kristal and Dubinsky, 1997; Berman et al., 2000; Brustovetsky and Dubinsky, 2000), suggesting that the differences in these results probably were due to the use of different methodologies in mitochondria isolation.

A higher resistance of brain mitochondria to the exposure to $\mathrm{Ca}^{2+}$ has been suggested to be due to the heterogeneity of the brain mitochondria population (Fig. 6Aa), composed of neuronal and glial mitochondria (Kristián et al., 2000; Berman et al., 2000). This suggestion can also be supported by the $\Delta \Psi \mathrm{m}$ data (Fig. 1Aa) showing that, after a first $\mathrm{Ca}^{2+}$ challenge, a small, transient release of mitochondrial $\mathrm{Ca}^{2+}$ occurred. This phenomenon suggests that some mitochondria underwent an induction of PTP and that $\mathrm{Ca}^{2+}$ released from this subpopulation was then accumulated by other mitochondria that did not release the accumulated $\mathrm{Ca}^{2+}$.

According to the different characteristics of mitochondria reported above, the potentiation of $A \beta$ peptide or $\mathrm{Ca}^{2+}$-induced depolarization was higher in liver mitochondria. A $\beta$ induced a decrease in the $\Delta \Psi \mathrm{m}$ (Figs. $1 \mathrm{Ab}, \mathrm{Bb}, 2 \mathrm{~A}, \mathrm{~B}$ ) and mitochondrial light scattering (only in liver mitochondria; Fig. 5Be,f,h), accelerating the induction of PTP. Parks et al. (2001) demonstrated that the induction of the mitochondrial permeability transition in 
isolated liver mitochondria by $\mathrm{A} \beta_{25-35}$ is concentrationdependent and requires calcium. In brain mitochondria, the increase in light scattering may be due to the exacerbation of $\mathrm{Ca}^{2+}$ precipitation by this peptide (Fig. 5Ad,e). These results are in agreement with other studies demonstrating that $A \beta$ peptides can cause a harmful elevation of intracellular calcium (Mattson et al., 1992; Weis et al., 1994; Mogensen et al., 1998). Potentiation of PTP induction in the presence of $A \beta$ suggests that, in the presence of this peptide, conditions that promote $\mathrm{Ca}^{2+}$ cycling exist (Figs. 1Ab,Bb, 2A,B, 5B).

Although $A \beta$ per se did not trigger the PTP, $\Delta \Psi \mathrm{m}$ data indicate that $A \beta$ alone decreased $\Delta \Psi \mathrm{m}$ (Figs. $1 \mathrm{Ab}, \mathrm{Bb}$, $2 A, B)$ This may be due to the capacity of $A \beta$ to interact with the mitochondrial redox chain and confirms the impairment of electron transfer along the respiratory chain (Fig. $4 \mathrm{Ab}, \mathrm{c}, \mathrm{Bb}$ ). The study of $\Delta \Psi \mathrm{m}$ is essential for an integrated evaluation of mitochondrial function, because it reflects differences in electrical potential and represents the main component of the proton electrochemical gradient, accounting for more than $90 \%$ of the total available respiratory energy (Nicholls, 1982). Moreover, the control of respiration in isolated mitochondria is well understood (Tager et al., 1983; Balaban, 1990). Resting coupled respiration (state 4) is controlled by the proton leak through the mitochondrial inner membrane and, to a lesser extent, by the respiratory chain (Brand et al., 1988). Conversely, the respiratory chain essentially controls uncoupled respiration. Therefore, changes in both parameters may indicate that the mitochondrial processes were affected. It was previously shown that other agents, such as protonophore uncouplers, decrease $\Delta \Psi \mathrm{m}$ and promote the induction of PTP.

Although our results show that $\mathrm{A} \beta$ promotes PTP opening, they did not refute the channel-forming ability of $A \beta$. As shown by others, $A \beta$ also can operate as a membrane channel, allowing the entry of ions, such as $\mathrm{Ca}^{2+}$ (Mirzabekov et al., 1994; Zhu et al., 2000), thus having an effect similar to that of other ion channelforming peptides, such as the protonophore gramicidin A (Cohen, 1975). However, the action of these compounds on mitochondrial permeability transition has not been evaluated.

A reduced rate of brain metabolism is one of the best-documented abnormalities in AD. The activities of several important enzymes of energy metabolism have been shown to be reduced in the AD brain. These include the pyruvate dehydrogenase complex, the $\alpha$-ketoglutarate dehydrogenase complex, and the cytochrome oxidase complex (Blass, 1997; Blass et al., 1997; Poirier et al., 1999). There is also strong evidence showing an increase in oxygen consumption in comparison with glucose utilization, in brain, from positron emission tomography (Fukuyama et al., 1994).

Our data also showed that $2 \mu \mathrm{M} \mathrm{A} \beta_{1-40}$ (Fig. 2A) had a similar toxic effect compared with that of $50 \mu \mathrm{M}$ $A \beta_{25-35}$ (Fig. 2B). The higher toxicity inherent to $A \beta_{1-40}$ comparatively to $A \beta_{25-35}$ was also shown by others (Her- tel et al., 1997). It is well known that all patients with $\mathrm{AD}$ accumulate some and usually many deposits of first $A \beta_{1-42}$ and then also $A \beta_{1-40}$ in regions of the brain important for memory, cognition, and behavioral stability. Although $A \beta_{25-35}$ is not found in vivo, insight into toxic effects associated with the longer $A \beta$ peptides is gained from the study of the simpler 11-mer $\left(A \beta_{25-35}\right)$. Several lines of evidence demonstrate that methionine 35 is the amino acid responsible for $A \beta$ peptide aggregation and neurotoxicity (Pike et al., 1995). The discrepancy between the concentrations of the two peptides $\left(50 \mu \mathrm{M} \mathrm{A} \beta_{25-35}\right.$ vs. $\left.2 \mu \mathrm{M} \mathrm{A} \beta_{1-40}\right)$ necessary to induce a similar toxic effect may be due to the fact that we used freshly dissolved $A \beta_{25-35}$ and "aged" $A \beta_{1-40}$. A correlation between the physical state of the peptide and its neurotoxic effects has been demonstrated in vitro by several authors (Busciglio et al., 1992; Pike et al., 1991, 1993). Those data led to the conclusion that maximal neurotoxicity is achieved when the peptide is aggregated in a fibrillary and not in an amorphous form (Lorenzo and Yankner, 1994).

The fact that the reverse sequence of $A \beta_{25-35}\left(A \beta_{35-25}\right)$ did not induce the PTP (data not shown) allows us to conclude that a specific sequence of amino acids is needed for the induction of PTP. Mattson et al. (1992) reported that the "reverse sequence" $A \beta_{35-25}$ is not cytotoxic. Also, in a cell-free-based assay, $A \beta_{25-35}$ generated ROS, whereas $A \beta_{35-25}$ did not. Furthermore, $A \beta_{25-35}$ was able to initiate synaptosomal lipoperoxidation, whereas $A \beta_{35-25}$ had no effect (Butterfield et al., 1994).

The PTP induction, a phenomenon characterized by a sudden increase in the permeability of the inner mitochondrial membrane, plays a key role in apoptotic cell death by facilitating the release of apoptogenic factors, such as cytochrome c. Cytochrome $\mathrm{c}$ is an essential component of the mitochondrial respiratory chain and, because of its heme group, can shuttle electrons between respiratory chain complexes III and IV. The release of cytochrome c leads to two potentially lethal consequences, a decrease in ATP synthesis and an overproduction of the radical superoxide anion (Skulachev, 1998).

Similarly to our results (Figs. 5A, 7Ab), Andreyev et al. (1998), using isolated rat forebrain and canine frontal cortex mitochondria, demonstrated that $\mathrm{Ca}^{2+}$ induces cytocrome c release, in vitro, by a mechanism that is not associated with mitochondrial swelling. $A \beta_{25-35}$ (Fig. $7 \mathrm{Bn}$ ) did not affect cytochrome $\mathrm{c}$ content or potentiate the $\mathrm{Ca}^{2+}$-induced cytochrome $\mathrm{c}$ release (Fig. 7Ac, 7Bh), probably because the 5 min preincubation of mitochondria with $A \beta_{25-35}$ was not sufficient to induce the release of cytochrome c. After $\mathrm{A}_{25-35^{-}}$and $\mathrm{Ca}^{2+}$-induced depolarization, EGTA (a $\mathrm{Ca}^{2+}$-chelating agent) and ADP (an inhibitor of PTP) plus oligomycin (which prevents ADP phosphorylation) completely repolarized mitochondria (Fig. 1A), as was previously demonstrated in other studies (Hunter and Haworth, 1979; Zoratti and Szabo, 1995; Kristal and Dubinsky, 2000).

Additional evidence that $A \beta_{25-35}$ promotes PTP induction is the protection exerted by the immunosuppres- 
sant peptide and specific inhibitor of PTP CsA. The effect of CsA on the ability of brain mitochondria to accumulate $\mathrm{Ca}^{2+}$ was only moderate compared with the effects described for CsA on liver or muscle mitochondria (Fontaine et al., 1998; Brustovetsky and Dubinsky, 2000; Dubinsky et al., 1999; Kristián et al., 2000). Similar effects of CsA were also found with cell lines (Murphy et al., 1996) and neuronal primary cultures (Dubinsky and Levi, 1998). Although CsA does not give total protection against PTP induction, it increases the capacity of brain mitochondria to accumulate $\mathrm{Ca}^{2+}$ (Fig. 3Ab). However, when ADP and oligomycin were present initially, the $\mathrm{A}_{25-35^{-}}$and $\mathrm{Ca}^{2+}{ }_{-}$ induced depolarization was prevented. Brustovestky and Dubinsky (2000) reported previously the protection exerted by ADP plus oligomycin on brain mitochondria before calcium challenge.

As observed by electron microscopy, CsA (Fig. 6Bd) and ADP plus oligomycin (Fig. 6Ad) induced protection against mitochondrial swelling. Furthermore, we observed that those agents rendered the cristae more compacted, suggesting a defense mechanism against toxic insults.

These findings demonstrate that the neurotoxic peptide $A \beta$ is shown to act as a respiratory chain uncoupler, capable of promoting the induction of PTP in both brain and liver mitochondria. Accordingly, the modulators of mitochondrial permeability transition and cytochrome $c$ release can be envisaged as the targets in novel therapies for neurodegenerative disorders.

\section{ACKNOWLEDGMENT}

P.I.M. is the recipient of grant PRAXIS XXI/BM/ 20952/99.

\section{REFERENCES}

Andreyev A, Fahy B, Fiskum G. 1998. Cytochrome c release from brain mitochondria is independent of the mitochondrial permeability transition. FEBS Lett 439:373-376.

Balaban RS. 1990. Regulation of oxidative phosphorylation in the mammalian cell. Am J Physiol 258:C377-C389.

Beal MF. 1995. Aging, energy, and oxidative stress in neurodegenerative diseases. Ann Neurol 38:357-366.

Beal MF. 1996. Mitochondria, free radicals and neurodegeneration. Curr Opin Neurobiol 6:661-666.

Berman SB, Watkins SC, Hastings TG. 2000. Quantitative biochemical and ultrastructural comparison of mitochondrial permeability transition in isolated brain and liver mitochondria: evidence for reduced sensitivity of brain mitochondria. Exp Neurol 164:415-425.

Bernardi P. 1992. Modulation of the mitochondrial cyclosporin A-sensitive permeability transition pore by the electrochemical gradient. J Biol Chem 267:8834-8839.

Bernardi P, Petronilli V. 1996. The permeability transition pore as a mitochondrial calcium release channel: a critical appraisal. J Bioenerg Biomembr 28:131-138.

Bernardi P, Broekemeier KM, Pfeiffer DR. 1994. Recent progress on regulation of the mitochondrial permeability transition pore, a cyclosporin-sensitive pore in the inner mitochondrial membrane. J Bioenerg Biomembr 26:509-517.

Blass JP. 1997. Cerebral metabolic impairments. In: Khachaturian ZS, Radebaugh TS, editors. Alzheimer's disease: cause(s), diagnosis, treatment, and care. New York: CRC Press. p 187-206.

Blass JP, Gibson GE, Hoyer S. 1997. Metabolism of the aging brain. In:
Mattson MP, Geddes JW, Tamiras P, Bittar EE, editors. Advances in cell aging and gerontology: the aging brain. London: JAI Press. p 109-128. Brand, MD, Hafner RP, Brown GC. 1988. Control of respiration in nonphosphorylating mitochondria is shared between the proton leak and the respiratory chain. Biochem J 255:535-539.

Broekemeier KM, Pfeiffer DR. 1995. Inhibition of the mitochondrial permeability transition by cyclosporin A during long time frame experiments: relationship between pore opening and the activity of mitochondrial phospholipases. Biochemistry 34:16440-16449.

Broekemeier KM, Dempsey ME, Pfeiffer DR. 1989. Cyclosporin A is a potent inhibitor of the inner membrane permeability transition in liver mitochondria. J Biol Chem 264:7826-7830.

Brustovetsky N, Dubinsky JM. 2000. Dual responses of CNS mitochondria to elevated calcium. J Neurosci 20:103-113.

Busciglio J, Lorenzo A, Yankner BA. 1992. Methodological variables in the assessment of beta amyloid neurotoxicity. Neurobiol Aging 13:609-612.

Butterfield DA, Hensley K, Harris M, Mattson MP, Carney J. 1994. $\beta$-Amyloid peptide free radical fragments initiate synaptosomal lipoperoxidation in a sequence-specific fashion: implications to Alzheimer's disease. Biochem Biophys Res Commun 200:710-715.

Cassarino DS, Fall CP, Smith TS, Bennett JP. 1998. Pramipexole reduces reactive oxygen species production in vivo and in vitro and inhibits the mitochondrial permeability transition produced by the parkinsonian neurotoxin methylpyridinium ion. J Neurochem 71:295-301.

Cassarino DS, Parks JK, Parker WD, Bennett JP Jr. 1999. The parkinsonian neurotoxin $\mathrm{MPP}^{+}$opens the mitochondrial permeability transition pore and releases cytochrome $\mathrm{c}$ in isolated mitochondria via an oxidative mechanism. Biochim Biophys Acta 1453:42-62.

Cay J, Jones DP. 1999. Mitochondrial redox signalling during apoptosis. J Bioenerg Biomembr 31:327-324.

Cohen BE. 1975. The permeability of liposomes to nonelectrolytes. I. Activation energies for permeation. J Membr Biol 20:205-234.

Dubinsky JM, Levi Y. 1998. Calcium-induced activation of the mitochondrial permeability transition in hippocampal neurons. J Neurosci Res 53:728-741.

Dubinsky JM, Brustovetsky N, Pinelis V, Kristal BS, Herman C, Li X. 1999. The mitochondrial permeability transition: the brain's point of view. Biochem Soc Symp 66:75-84.

Dyrks T, Dyrks E, Hartamnn T, Masters C, Beyreuther K. 1992. Amyloidogenicity of $\beta A 4$ and $\beta A 4$-bearing amyloid protein precursor fragments by metal-catalyzed oxidation. J Biol Chem 267:18210-18217.

Estabrook RE. 1967. Mitochondrial respiratory control and the polarographic measurement of ADP/O ratios. Methods Enzymol 10:41-47.

Fontaine E, Eriksson O, Ichas F, Bernardi P. 1998. Regulation of the permeability transition pore in skeletal muscle mitochondria. Modulation by electron flow through the respiratory chain complex I. J Biol Chem 273:12662-12668.

Fukuyama HM, Ogawa H, Fukuyama HM, Ogawa H, Yamaguchi H, Yamaguchi S, Kimura J, Yonekura Y, Konishi J. 1994. Altered cerebral energy metabolism in Alzheimer's disease: a PET study. J Nucl Med 35:1-6.

Gazotti P, Malmstron K, Crompton M. 1979. A laboratory manual on transport and bioenergetics. In: Carafoli E, Semenza G, editors. Membrane biochemistry. New York: Springer Verlag. p 62-69.

Glenner GG, Wong CW. 1984. Alzheimer's disease: initial report of the purification and characterization of a novel cerebrovascular amyloid protein. Biochem Biophys Res Commun 120:885-890.

Gornall AG, Bardawill CJ, David MM. 1949. Determination of serum proteins by means of the biuret reaction. J Biol Chem 177:751-766.

Gunter TE, Gunter KK, Sheu SS, Gavin CE. 1994. Mitochondrial Ca ${ }^{2+}$ transport: physiological and pathological relevance. Am J Physiol 267: C313-C339. 
Henry TR, Solem LE, Wallace KB. 1995. Channel-specific induction of the cyclosporin A-sensitive mitochondrial permeability transition by menadione. J Toxicol Environ Health 45:489-504.

Hensley K, Carney JM, Mattson MP, Aksenova M, Harris M, Wu JF, Floyd RA, Butterfield DA. 1994. A model for $\beta$-amyloid aggregation and neurotoxicity based on free radical generation by the peptide: relevance to Alzheimer's disease. Proc Natl Acad Sci USA 91:3270-3274.

Hertel C, Terzi E, Hauser N, Jakob-Rotne R, Seelig J, Kemp JA. 1997. Inhibition of the electrostatic interaction between beta-amyloid peptide and membranes preventsbeta-amyloid-inducedtoxicity. Proc Natl Acad Sci USA 94:9412-9416.

Hunter DR, Haworth RA. 1979. The $\mathrm{Ca}^{2+}$-induced membrane transition in mitochondria. I. The protective mechanisms. Arch Biochem Biophys 195:453-459.

Jensen BD, Gunter TE. 1984. The use of tetraphenylphosphonium $\left(\mathrm{TPP}^{+}\right)$ to mesure membrane potentials in mitochondria: membrane binding and respiratory effects. Biophys J 45:92a.

Kamo N, Muratsugu M, Hongoh R, Kobatake V. 1979. Membrane potential of mitochondria measured with an electrode sensitive to tetraphenylphosphonium and relationship between proton electrochemical potential and phosphorylation potential in steady state. J Membr Biol 49:105-121.

Kristal BS, Dubinsky JM. 1997. Mitochondrial permeability transition in the central nervous system: induction by calcium cycling-dependent and -independent pathways. J Neurochem 69:524-538.

Kristián T, Gertsch J, Bates TE, Siesjö BK. 2000. Characteristics of the calcium triggered mitochondrial permeability transition in nonsynaptic brain mitochondria: effect of cyclosporin A and ubiquinone 0. J Neurochem 74:1999-2009.

Lorenzo A, Yankner BA. 1994. Beta-amyloid neurotoxicity requires fibril formation and is inhibited by Congo red. Proc Natl Acad Sci USA 91:12243-12247.

Mattson MP, Cheng B, Davis D, Bryant K, Lieberburg I, Rydel RE. 1992. $\beta$-Amyloid peptides destabilize calcium homeostasis and render human cortical neurons vulnerable to excitotoxicity. J Neurosci 12:376-389.

Mirzabekov T, Lin M, Yuan WL, Marshall P, Carman M, Tomaselli K, Lieberberg I, Kagan BL. 1994. Channel formation by a neurotoxic fragment of the beta-amyloid peptide. Biochem Biophys Res Commun 202:1142-1148

Mogensen HS, Beatty DM, Morris SJ, Jorgensen OS. 1998. Amyloid $\beta$-peptide $(25-35)$ changes $\left[\mathrm{Ca}^{2+}\right]$ in hippocampal neurons. NeuroReport 9:1553-1558.

Muratsugu M, Kamo N, Kurihara K, Kobatake Y. 1977. Selective electrode for dibenzyl dimethyl ammonium cation as indicator of the membrane potential in biological systems. Biochim Biophys Acta 464:613-619.

Murphy AN, Bredesen DE, Cortopassi G, Wang E, Fiskum G. 1996. Bcl-2 potentiates the maximal calcium uptake capacity of neuronal cell mitochondria. Proc Natl Acad Sci USA 93:9893-9898.

Nicholls DG. 1982. An introduction to chemiosmotic theory. In: Bioenergetics. New York: Academic Press.

Palmeira CM, Wallace KB. 1997. Benzoquinone inhibits the voltagedependent induction of the mitochondrial permeability transition caused by redox-cycling naphthoquinones. Toxicol Appl Pharmacol 143:338347.
Parks JK, Smith TS, Trimmer PA, Bennett JP Jr, Parker WD Jr. 2001. Neurotoxic $A \beta$ peptides increase oxidative stress in vivo through NMDA-receptor and nitric-oxide-synthase mechanisms, and inhibit complex IV activity and induce a mitochondrial permeability transition in vitro. J Neurochem 76:1050-1056.

Pereira C, Santos MS, Oliveira C. 1999. Involvement of oxidative stress on the impairment of energy metabolism induced by A $\beta$ peptides on PC12 cells: protection by antioxidants. Neurobiol Dis 6:209-219.

Petronilli V, Costantini P, Scorrano R, Passamonti S, Bernardi P. 1994. The voltage sensor of the mitochondrial permeability transition pore is tuned by the oxidation-reduction state of vicinal thiols. J Biol Chem 269:16638-16642.

Pike CJ, Cotman CW. 1993. Cultured GABA-immunoreactive neurons are resistant to toxicity induced by $\beta$-amyloid. Neuroscience 56:269-274.

Pike CJ, Walencewicz AJ, Glabe CG, Cotman CW. 1991. In vitro aging of beta-amyloid protein causes peptide aggregation and neurotoxicity. Brain Res 563:311-314.

Pike CJ, Burdick D, Walencewicz AJ, Glabe CG, Cotman CW. 1993. Neurodegeneration induced by $\beta$-amyloid peptides in vitro: the role of peptide assembly state. J Neurosci 13:1676-1687.

Pike CJ, Walencewicz-Wasserman AJ, Kosmoski J, Cribbs DH, Glabe CG, Cotman CW. 1995. Structure-activity analyses of beta-amyloid peptides: contributions of the beta $25-35$ region to aggregation and neurotoxicity. J Neurochem 64:253-265.

Poirier J, Danik M, Blass JP. 1999. Pathophysiology of the Alzheimer syndrome. In: Gautier S, editor. Clinical diagnosis and management of Alzheimer's disease. London: Martin Dunitz. p 17-32.

Richter C, Kass GEN. 1991. Oxidative stress in mitochondria: its relationship to cellular $\mathrm{Ca}^{2+}$ homeostasis, cell death, proliferation, and differentiation. Chem Biol Interact 77:1-23.

Rosenthal RE, Hamud F, Fiskum G, Varghese PJ, Sharpe S. 1987. Cerebral ischemia and reperfusion: prevention of brain mitochondrial injury by lidoflazine. J Cereb Blood Flow Metab 7:752-758.

Selkoe DJ, Yamazaki T, Citron M, Podlisny MB, Koo EH, Teplow B, Haass C. 1996. The role of APP processing and trafficking pathways in the formation of amyloid beta-protein. Ann N Y Acad Sci 777:57-64.

Shigenaga MK, Hagen TM, Ames BN. 1994. Oxidative damage and mitochondrial decay in aging. Proc Natl Acad Sci USA 91:10771-10778.

Skulachev VP. 1998. Cytochrome $\mathrm{c}$ in the apoptotic and antioxidant cascades. FEBS Lett 423:275-280.

Tager JM, Wanders RJA, Groen AK, Kunz W, Bohnensack R, Kuster U, Letko G, Bohme G, Duszynski J, Wojtczak L. 1983. Control of mitochondria respiration. FEBS Lett 151:1-9.

Weis M, Kass GEN, Orrenius S. 1994. Further characterization of the events involved in mitochondrial $\mathrm{Ca}^{2+}$ release and pore formation by prooxidants. Biochem Pharmacol 47:2147-2156.

Wingrove DE, Gunter TE. 1985. $\mathrm{Na}^{+}$dependent $\mathrm{Ca}^{2+}$ efflux in rat liver mitochondria. Fed Proc 44:1082-1087.

Zhu YJ, Lin H, Lal R. 2000. Fresh and nonfibrillary amyloid $\beta$ protein $(1-40)$ induces rapid cellular degeneration in aged human fibroblasts: evidence for A $\beta$ P-channel-mediated cellular toxicity. FASEB J 14:12441254.

Zoratti M, Szabo I. 1995. The mitochondrial permeability transition. Biochim Biophys Acta 1241:139-176. 